\title{
Some Government Skin in the Game: How to Encourage New Technology
}

\author{
David C. Colander \\ Department of Economics, Middlebury College, Middlebury, Vermont 05753, USA.
}

Eastern Economic Journal (2014) 40, 143-145. doi:10.1057/eej.2014.10

There has been a lot of debate recently about whether government should be encouraging new technologies. Most of that debate has taken it as given that if the government is to encourage new technology, it does so with loan guarantees and subsidized loans. That is a prescription for failure. The recent flare-up over the failed loans and the case of Solyndra and Fisker are only the most recent examples. Republicans point out, quite rightly, that these loans failed, and were far too risky for the government to have made. Democrats respond, quite rightly, that the loans were meant to be risky — that with new technologies many approaches fail, but unless one tries one misses out on those technologies that succeed, and unless the United States leads its new technologies it will lose its competitive advantage.

What the Democratic argument misses is what would have happened if the encouraged technology had been a success. In that case, the government would have gotten its money back, along with a small interest payment. The private investors would have made billions. Encouraging new technologies with loans and loan guarantees gives the downside risk to the government and the upside benefit to private investors; it directs most of the benefits to the few. That is a prescription for political pressure and crony capitalism.

The reality is that new technology is far too risky to be financed by loans - whether they be private or government. One would need usurious interest rates of 50 percent or more to compensate for the inherent risk in non-collateralized loans for new technology, and no new technology firm would pay that. That's why startup technologies are funded by collateralized loans taken out by entrepreneurs, by venture capitalists, or by private equity firms who demand a major back-end equity position in the successful firm.

The scrutiny that new technologies receive from these funders is severe. Entrepreneurs are pushed to demonstrate the realistic possibilities (as opposed to the pie-in-the-sky possibilities envisioned by starry-eyed enthusiasts) of the technologies. This scrutiny gives those new technologies that make it through the financing ordeal a fighting chance to succeed. It forces the entrepreneurs to make the hard decisions necessary to bring a new technology to market. The process works because everyone involved has skin in the game; the more layers of skin the better. Many technologies still fail, but if the venture capitalists and private investors have fulfilled their role, the successful technologies make up for the failures.

Government loans or loan guarantees reduce the private skin in the game, and thereby undermine the needed market assessment process of new technologies. When government 
loans are involved, the likelihood of failures increases and the likelihood of successes decreases since the private cost of failure is reduced.

Reasonable supporters of the government encouragement of new technologies accept the above reasoning, but argue that it doesn't take into account the positive externalities associated with new technologies. If a new technology takes off, it will underpin future US growth, and the benefits will extend to everyone, not just to the investors. Private investors don't take that growth externality into account and thus we don't get enough private investment in new technology. It follows that government involvement is needed.

The problem with this argument is that while it may justify a small subsidy for new technologies, it doesn't justify the large asymmetric subsidies that loans involve. Loans give private investors most of the benefits if the technology is successful, and the government gets most of the costs if it isn't. That is an invitation for failure.

Some argue that the problem with loans means that the government should not play any role in encouraging new technology. But that doesn't necessarily follow. What it does mean is that government loans or loan guarantees are not the right vehicles for government encouragement of new technology. Instead of encouraging new technologies by loans, a more appropriate structure for government encouragement of new technologies would be the public equivalent to a private venture capital company or private equity firm. The encouraging would be in the form of a government investment in the technology, not a loan.

That investment would give the government an ownership position in the company. If the company goes under, then, as in the case of Fisker and Solyndra, the government loses most of its investment. But if the company is successful, then the government gets not only its money back, but also a much higher return commensurate with the government's investment. With public equity investments, the government shares equally in both the new technology successes and failures, rather than just in the failures as it does with loans.

Once the new technology is off the ground, the government can sell off its share of the investment to private investors, and use the proceeds to finance other new technologies. Such a program could and should be self-sustaining. If it doesn't become self-sustaining, then it should be shut down.

Government ownership scares people, and rightly so. For such a plan to work, the agency in charge of the government encouragement would have to be created such that it is at an arm's length from direct political pressure - something along the lines of the Federal Reserve System. It would be given some initial seed funding, and a mandate to earn sufficient returns on its investment to become self-sustaining. It will have government skin in the game, and government managers will have their job and their pay depending on having more winners than losers, just as would be the case with a private firm. Future investments in new technologies would come from returns on past investments, not from new government funding. If the plan has no big successes to offset its failures, it would be shut down.

Structuring government encouragement of new technology in this way would reduce the demand for government involvement significantly, because it would no longer involve asymmetrical risk bearing by the government. Those who want government support will have to give the government back a portion of the gains, just as they would with private financing. Using public equity investments, the successes can pay for the failures with the returns from its successes, and the government involvement will be less of a subsidy and more of a reasonable investment.

So where is the government subsidy for the growth externality of the new technology? It is built into the program since the government agency's goal is self-sustainability, not large 
profits. That gives it a little more leeway in its decision process than a private investor would have.

Creating such a program that is actually workable is not easy. Good new government programs are as difficult to institute as good new technologies. But they are worth developing because the demand for government support of new technologies will continue. They must however be developed with a hard-eyed realism of the difficulties, not with the starry-eyed enthusiasm of someone with no skin in the game.

Currently, the demand for the government to encourage new technologies is leading to programs of loans and loan guarantees, which are definitely the wrong conduit for government encouragement. Those loans do far more damage than good, and they cost the government large amounts of money. If government encouragement of new technology is to take place, it has to be done in a way that doesn't almost guarantee failure and undermine the market's method for discipline in making investments in new technology. 